УДК 332.146:330.341.1

JEL L83, O 18, O 31, R 19

DOI 10.31375/2226-1915-2019-4-5-14

І.В. Савельсва

д.е.н., професор, завідувач кафедри «Підприємництво та туризм» savirina@gmail.com

ORCID https://orcid.org/0000-0002-6492-2130

Одеський національний морський університет, Одеса, Україна

\section{РОЗВИТОК КРУЇЗНОГО ТУРИЗМУ В УМОВАХ ВИКОРИСТАННЯ МЕТОДИКИ СМАРТ-СПЕЦІАЛІЗАЦЇ ОДЕСЬКОЇ ОБЛАСТІ}

Анотація. Для сталого розвитку економіки державі потрібні об'єктивні методи розподілу бюджетного фінансування по регіонам. Але в умовах обмеженості фінансових ресурсів держави, їх розподіл між регіонами має здійснюватися за чіткими критеріями $i$ пріоритетами. В умовах посилення інтеграції з Європейським Союзом слід звернути увагу на впроваджені в міжнародну практику інновачійні підходи, методи та інструменти розподілу фінансування суб'єктів економічної системи. На сьогоднішній день одним з найбільш інноваиіийних підходів є смарт-спеціалізація європейських регіонів, яка використовується в тому числі європейськими структурними та інвестииійними фондами. Згідно з иим підходом економічна політика держави в регіональному вимірі має враховувати унікальні можливості для розвитку та зростання конкретного регіону, його конкурентні переваги, його пріоритетні сфери для розвитку та інвестицій, інноваційну орієнтованість, можливості крос-секторального підходу та інше.

Одеська область наряду з іншими областями Украӥни була обрана в якості пілотної для апробаиї та розповсюдження досвіду впровадження інструментів смарт спеціалізації в регіональній стратегії розвитку. За результатами аналізу видів економічної діяльності регіону виявилось, щэо такі традичійні для Одеси ніші як транспорт та туризм не потрапили до переліку найбільш конкурентоздатних та ефективнux.

(C) Савельєва I.B., 2019
Найбільи негативним є той факт, щуо навіть такий перспективний та потениійно ефективний бізнес, як круїзний туризм може залишитись без підтримки держави, якщзо підприємства иъього сектору не оберуть курс прозорості, інноваційності та сочіальної відповідальності.

Ключові слова: смарт-спеціалізачія, круїзний туризм, регіональна стратегія розвитку, державне фінансування.

УДК 332.146:330.341.1

JEL L83, O 18, O 31, R 19

DOI 10.31375/2226-1915-2019-4-5-14

И.В. Савельева

д.э.н., профессор, заведующая кафедрой «Предпринимательство и туризм» savirina@gmail.com

ORCID https://orcid.org/0000-0002-6492-2130

Одесский национальный морской университет, Одесса, Украина

РАЗВИТИЕ КРУИЗНОГО ТУРИЗМА В УСЛОВИЯХ ИСПОЛЬЗОВАНИЯ МЕТОДИКИ СМАРТ-СПЕЦИАЛИЗАЦИИ ОДЕССКОЙ ОБЛАСТИ

\begin{abstract}
Аннотация. Для устойчивого развития экономики государству нужны объективные методы распределения бюджетного финансирования по регионам. Но в условиях ограниченности финансовых ресурсов государства, их распределение между регионами должно осуществляться по четким критериям и приоритетам. В условиях усиления интеграции с Европейским Союзом следует обратить внимание на используемые в международной практике инновационные подходы, методы и инструменты распределения финансирования субъектов экономической системы. На сегоднямний день одним из самых инновационных подходов является смарт-специализачия европейских регионов, которая используется в том числе европейскими структурными и инвестиционными фондами. Согласно этому подходу экономическая политика государства в региональном разрезе должна учитывать уникальные возможности для развития $и$ роста конкретного региона, его конкурентные преимущества, его приоритетные сферы для развития и инвестиций, инновационную ориентированность, возможности кросс-секторального подхода и прочее.
\end{abstract}


Одесская область наряду с другими областями Украины была выбрана в качестве пилотной для апробации и распространения опыта внедрения инструментов смарт-сnецииализации в региональной стратегии развития. По результатам анализа видов экономической деятельности региона оказалось, что такие традиционные для Одессы ниши как транспорт и туризм не попали в список самых конкурентоспособных и эффективных. Наиболее негативным является тот факт,

UDC 332.146:330.341.1

JEL L83, O 18, O 31, R 19

DOI 10.31375/2226-1915-2019-4-5-14

что даже такой перспективный и потенщиально эфффективный бизнес, как круизный туризм может остаться без поддержки государства, если предприятия этого сектора не выберут курс прозрачности деятельности, инновационности и социальной ответственности.

Ключевые слова: смарт-спечииализачия, круизный туризм, региональная стратегия развития, государственное финансирование.

I.V. Savelieva

DSc (Econ.), Professor, Head of Department «Entrepreneurship and tourism» savirina@gmail.com

ORCID https://orcid.org/0000-0002-6492-2130

Odessa National Maritime University, Odessa, Ukraine

\title{
CRUISE TOURISM DEVELOPMENT UNDER THE CONDITIONS OF SMART SPECIALIZATION TECHNIQUES
}

\begin{abstract}
Development of the theoretical foundations of a «smart economy», its impact on economic, scientific and technological specialization of the region, and therefore on its performance, competitive ability and economic growth is an important task. This article describes the concept of smart specialization of the regions, which aims to identify measures to incentives to efficiently, systemically develop the economy by using creativity, innovative human-specific skills capital information and communication technologies.

For the sustainable development of the economy, Ukraine needs objective methods for distributing budget financing by regions. But in the circumstances of limited financial resources, the funds allocation between regions should be carried out according to clear criteria and priorities. In the context of increased integration with the European Union, attention should be paid to the innovative approaches used in international practice, methods and tools for distributing the financing of economic entities. Today, one of the most innovative approaches is the smart specialization of European regions, which is also used by European structural and investment funds. According to this approach, the economic policy of the central government in the regional context should take into account the unique opportunities for the development and growth of a particular region, its competitive advantages, its priority areas for development and investment, innovative orientation, the possibilities of a cross-sectoral approach, etc.

The Odessa region, along with other regions of Ukraine, was chosen as a pilot for testing and disseminating the experience of introducing smart specialization tools in a regional development strategy. According to the analysis of the types of economic activity in the region, it turned out that such traditional Odessa niches as transport and tourism, were not included in the list of the most competitive and efficient ones. The most negative aspect is the fact that even such a promising and potentially efficient business activity as cruise tourism can remain without state support if the enterprises of this sector do not choose a course of transparency, innovation and social responsibility.
\end{abstract} financing.

Keywords: smart specialization, cruise tourism, regional development strategy, state 
РОЗВИТОК МЕТОДІВ

УПРАВЛІННЯ ТА ГОСПОДАРЮВАННЯ

НА ТРАНСПОРТІ, № 4 (69), 2019
Постановка проблеми. Державна стратегія регіонального розвитку спрямована на визначення завдань i інструментів для вирішення соціальних проблем регіонів, підвищення рівня їх економічного потенціалу, продуктивності їх економіки, прибутковості бізнесу і доходів населення i, як наслідок, створення умов для загального підвищення соціальних стандартів, якості життя та розвитку бізнес-середовища. В умовах обмеженості фінансових ресурсів держави, їх розподіл між регіонами має здійснюватися за чіткими критеріями і пріоритетами. Саме тому проблема визначення цих пріоритетів розподілу ресурсів і концентрування їх на тих заходах і територіях, які можуть забезпечити високий результат в найкоротші терміни і мати тривалий i комплексний вплив на розвиток не тільки даного регіону, а й сусідніх територій, має таке велике значення для бюджету країни.

Питання ефективного розподілу державного бюджетного фінансування актуальні для будь-якої країни. Очевидно, що в умовах зростаючої інтеграції української економіки $з$ економікою Європейського Союзу варто звернути увагу на можливість і ефективність впровадження в практику суб'єктів економічної системи України тих же підходів, методів та інструментарію, якими користуються європейські структури. На сьогоднішній день одним 3 найбільш інноваційних інструментів $є$ смарт-спеціалізація європейських регіонів, який використовується в тому числі європейськими структурними та інвестиційними фондами.

Огляд останніх досліджень та літератури. Основними розробника- ми концепції смарт-спеціалізації $\epsilon$ провідні вчені-економісти і експерти в області економіки знань, серед яких найбільший внесок у виникнення, розвиток і практичне впровадження ідеї був зроблений Д. Форе [1], П. Давидом [2], Б. Холом [2] і Б. ван Арком [1]. Їх розробки і рекомендації заклали базис для розвитку нової парадигми створення конкурентних переваг регіонів на підставі подолання бар'єрів регіонального розвитку. Автори акцентували увагу на необхідності чіткого розуміння сутності спеціалізації, виявлення особливостей i відмінностей від всіх раніше застосовуваних інструментів регіонального розвитку. В першу чергу в їх роботах робиться акцент на міжгалузевий характер і новизну підходу. Окремі теоретико-прикладні аспекти застосування концепції смарт-спеціалізації розкриті в працях вітчизняних дослідників, зокрема Я. Бжуска, Я. Піка [3], . Дубінського [4], Я.А. Жаліло [5], В.І. Жука [5], О.Ю. Снігової [6] та ін. В цілому смарт-спеціалізація позиціонується авторами як модель територіального розвитку, яка заснована на структурних змінах, орієнтованих на створення конкурентних переваг регіональних економік за рахунок спеціалізованої диверсифікації і перенесення інновацій. У той же час, системних досліджень впливу смарт-спеціалізації розвитку регіону на підвищення его конкурентоспроможності та інноваційної активності досі проведено не було.

Задачі дослідження. Метою дослідження $\epsilon$ аналіз можливостей застосування європейської методики соціально-економічної оцінки регіонів для України. 
DEVELOPMENT OF MANAGEMENT

AND ENTREPRENEURSHIP METHODS ON TRANSPORT, № 4 (69), 2019
РОЗВИТОК МЕТОДІВ

УПРАВЛІННЯ ТА ГОСПОДАРЮВАННЯ

НА ТРАНСПОРТІ, № 4 (69), 2019
Основний матеріал дослідження. Виходячи 3 траєкторії соціально-економічного розвитку України можна стверджувати, що в найближчій перспективі реалізація потенціалу кожного регіону в значній мірі буде залежати від того, як буде побудований процес його стратегічного планування. Державні кошти будуть направлятися на фінансування проектів регіонального розвитку тільки відповідно до якісно розроблених регіональних стратегічних документів.

Регіональна стратегія розвитку - це довгостроковий план, який визначає цілі, завдання, пріоритети, напрямки стійкого економічного i соціального розвитку конкретного регіону.

Останні законодавчі акти, а саме Закон України «Про засади державної регіональної політики», Закон України «Про стимулювання розвитку регіонів», постанова Кабінету міністрів України від 6 серпня 2014 року № 385 «Про затвердження державної стратегії регіонального розвитку на період до 2020 року», а також постанов кабінету міністрів України від 11 листопада 2015 року № 931 «Про затвердження Порядку розроблення державної стратегії регіонального розвитку України і план заходів з іiі реалізації, а також проведення моніторингу та оцінки результативності реалізації зазначеним Стратегії і плану заходів» та № 932 «Про затвердження Порядку розроблення регіональних стратегій розвитку и планів заходів 3 їх реалізації, а також проведення моніторингу та оцінки результативності реалізації зазначених регіональних стратегій і планів заходів» визначають обов'язкове застосування в стратегічних пла- нах розвинення регіонів підходів смарт-спеціалізації, яка передбачає аргументоване визначення в рамках регіональної стратегії перспективних цілей і завдань 3 розвитку видів економічної діяльності, які мають інноваційний потенціал 3 урахуванням конкурентних переваг регіону і сприяють трансформації секторів економіки в більш ефективні [6].

Оскільки Одеська область була обрана в якості однієї з пілотних областей для апробації інструментарію смарт-спеціалізації в Україні [7], iii регіональна стратегія до 2027 року має спиратися на методологію [8], в рамках якої визначаються пріоритети для створення конкурентних переваг, що відповідають новим можливостям розвитку регіону, а також досягається уникнення дублювання та фрагментації дослідницької та інноваційної діяльності. Інноваційна європейська методологія опосередковано сприяє збалансованості та постійному поліпшенню якості життя громадян завдяки збалансованому розвитку регіонів и громад, створенню нових робочих місць та інших економічних можливостей, забезпеченню надання якісних публічних послуг з високим рівнем доступності, забезпеченню чистого та безпечного середовища проживання та просування досліджень та інновацій в рамках застосування смарт-спеціалізації.

Методологія регіонального розвитку на базі інструментарію смарт спеціалізації включає кілька етапів.

Як зображено на рисунку, в основі прийняття рішень щодо стратегічних напрямків розвитку регіону лежить соціально-економічний аналіз. 


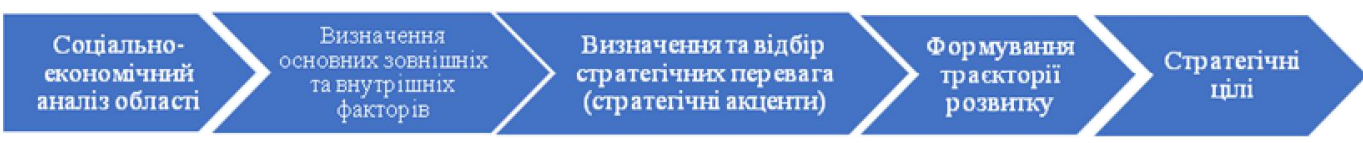

Рисунок. Етапи визначення смарт-спещіалізащії регіону [8]

Соціально-економічний аналіз (СЕА) є однією з ключових складових формування регіональної стратегії розвитку. Саме СЕА лягає в основу розробки можливих сценаріїв розвитку, визначення сильних та слабких сторін регіону, визначення стратегічних напрямків розподілу бюджетного фінансування та концентрації інвестиційних, інтелектуальних і трудових ресурсів стейкхолдерів.

Слід підкреслити, що в Україні та й в ЄС до теперішнього часу не існує формалізованих підходів до підготовки CЕА, але вже сформовані загальні принципи відносно структури такого документу та рівня деталізації даних. Соціальноекономічний аналіз повинен охоплювати всі важливі аспекти життєдіяльності и розвитку цільового регіону. Якісно зроблений и адекватно використаний аналіз ситуації дозволяє краще зрозуміти актуальний стан та тенденції в економічній, соціальній, екологічній та інноваційній сфеpax регіону. Цей аналіз також створює потужню основу для своєчасного виявлення бажаних и небажаних змін в регіоні, а також основу для прийняття обгрунтованих рішень відносно регіонального розвитку.

Підготовка якісного CEA $\epsilon$ дуже важливим елементом для всієї роботи над регіональною стратегією розвитку, адже саме CEA дає змогу визначити сильні та слабкі сторони регіону, оцінити можливі сценарії розвитку та визначити внутрішні ре- сурси и конкурентні переваги регіону перед іншими територіями.

CEA готується на підставі відкритих даних обласного управління статистики, податкової служби, управлінь обласних державних адміністрацій, а також Держстату України. При підготовці СЕА бажано використання схем планування територій області, а також матеріалів статистичних даних міжнародного економічного форуму, світового банку, публікацій науково-дослідних інститутів, дослідницьких та аналітичних центрів, соціологічних служб.

CЕА має буті досить детальним, але водночас не переобтяженим надмірною кількістю цифрових даних та розлогих текстів наукового характеру [9].

Виконані за сформованим європейською методикою розрахунки для Одеської області $[10 ; 11]$ продемонстрували як економічний, так і інноваційний потенціал та перспективність розвитку таких напрямків економічної діяльності:

- перероблення та консервування фруктів і овочів (КВЕД 10.3);

- виробництво основної хімічної продукції, добрив і азотних сполук, пластмас і синтетичного каучуку в первинних формах (КВЕД 20.1);

- виробництво проводів, кабелів і електромонтажних пристроїв (КВЕД 27.3);

- виробництво машин і устаткування для сільського та лісового господарства (КВЕД 28.3); 
DEVELOPMENT OF MANAGEMENT AND ENTREPRENEURSHIP METHODS ON TRANSPORT, № 4 (69), 2019
РОЗВИТОК МЕТОДІВ

УПРАВЛІННЯ ТА ГОСПОДАРЮВАННЯ

НА ТРАНСПОРТІ, № 4 (69), 2019
- виробництво медичних і стоматологічних інструментів і матеріалів (КВЕД 32.5).

Ці види діяльності були визначені на основі поточної сильної спеціалізації і середньої заробітної плати на одного працівника. Інноваційний потенціал пояснюється, головним чином, відносно високою часткою інновацій продуктів та маркетингових інновацій у 2014 р. та 2016 р.

При цьому, слід звернути увагу, що ні транспортне забезпечення, ні туризм та його інфраструктура взагалі не фігурують у переліку пріоритетних та потенційно перспективних галузей економічної діяльності. Така ситуація, звичайно, говорить про недосконалість статистичної звітності підприємств таких традиційних для Одеси видів економічної діяльності.

У цьому контексті слід звернути увагу на таку унікальну для України нішу, як круїзний туризм. Одеса і область мають значний науковий, виробничий, технічний і фінансовий потенціал для того, щоб перетворити цей сектор діяльності в один 3 унікальних у масштабах регіону і країни в цілому. Розвиток діяльності у цій ніші об'єднує концентрацію зусиль підприємств як транспортної галузі, так і туристичної. Крім того, цей напрям діяльності динамічно розвивається.

За результатами 2018 року світовий круїзний бізнес можна охарактеризувати наступними показниками [11]: 386 круїзних суден, перевезено 26,7 мільйона пасажирів. Дохід від продажів склав 40 більйонів. Частки основних круїзних ринків у 2018 році: Північна Америка 54,8 \%, Свропа $27,8 \%$, Азія / Тихий океан $-17,4 \%$.
Несприятлива геополітична обстановка на Чорному морі (події в Криму і на Сході України, напружені відносини між Україною і Росією, терористичні акти в Туреччині) у період з 2014 по 2019 роки та пов'язані з нею різні фактори ризику привели до $90 \%$ скорочення кількості заходів круїзних суден в Чорноморський регіон 3 Середземного моря. У 2018 році круїзні лайнери під іноземним прапором не заходили в Одеський порт [13]. У 2017 році відбувся один захід пасажирського судна під іноземним прапором в Одесу, в 2016 р. - п'ять, y 2015 p. - 13, у 2014 p. - 28, y 2013 p. - 106, y 2012 p. - 80, y 2011 p. - 74, y 2010 p. - 72, y 2009 p. -58, y 2008 p. -75, y $2007-69$ [12].

Тепер у зв'язку з певною стабілізацією ситуації прогнозується зростання суднозаходів міжнародних круїзних компаній в сезон 2020-2021 і наступні роки. Відомі туристичні оператори «Фенікс Райзен», «Азамара», «Кристал Крузес» та інші знову включають Одесу в маршрути своїх круїзів з заходом у Чорне море [13].

Однак фактори ризику для повномасштабного залучення круїзних лайнерів міжнародних круїзних ліній 3 Середземного моря зберігаються.

Звичайно, необхідно позначити зовнішні, пов'язані з політичною обстановкою в регіоні, ризики і складності:

- Крим знаходиться поза міжнародними круїзними маршрутами після 2014 року, що руйнує раніше вста-новлену модель чорноморського круї-зу з типовими 2-3 заходами в порти Чорного моря з Середземного моря, де один 3 портів Криму повинен був бути обов'язковим; 
РОЗВИТОК МЕТОДІВ

УПРАВЛІННЯ ТА ГОСПОДАРЮВАННЯ

НА ТРАНСПОРТІ, № 4 (69), 2019
- політичні проблеми у відносинах між Україною і Росією, а також періодичні проблеми у взаєминах між Росією і Туреччиною;

- політична і економічна нестабільність в деяких країнах регіону, потенційна небезпека терористичних атак в деяких портах.

Вищезазначені фактори ризику, які розглядаються міжнародними круїзними лініями, є наслідком глобальних геополітичних процесів і значно ускладнюють розвиток круїзного судноплавства в Чорноморському регіоні.

Тим не менш, $є$ багато важливих факторів, що сприяють розвитку круїзного туризму в Чорному морі, які повинні бути враховані місцевою владою і бізнес-структурами при формуванні стратегії розвитку регіону, а саме:

- напруженість середземноморських портів у «високий сезон»;

- введення екологічних обмежень на види палива для круїзних суден у Балтійському морі;

- відносно короткі відстані між портами Чорного моря забезпечують мінімізацію витрат і максимізації пропозиції екскурсійного часу для туристів;

- відкладений попит на круїзи у невідомому регіоні.

Але попит вимагає утримання. Для того, щоб закріпити інтерес до Чорного моря, всім зацікавленим сторонам необхідно сконцентруватися на:

- формуванні Чорноморського туристичного продукту;

- просуванні бренду Чорного моря на міжнародному туристичному i круїзному ринках за допомогою участі у міжнародних виставках;
- консолідованому підході і взаємодії країн Чорноморського регіону як привабливих круїзних напрямків;

- створенні інформаційної платформи для всіх учасників круїзного ринку;

- проведенні зустрічей і презентацій для представників міжнародних круїзних ліній;

- організації рекламно-ознайомлювальних турів для представників круїзних компаній.

Що стосується конкретних завдань, то акцент необхідно зробити на наступних найбільш важливих:

- розширення асортименту берегових екскурсії не тільки в Одесі, але і в області;

- розробка історичних та екологічних турів за межами міста - аж до 150 км від міста;

- відновлення системної підготовки гідів, організація мовних курсів для обслуговуючого персоналу;

- впровадження гнучкої тарифної політики з боку об'єктів показу;

- збереження i відновлення культурної спадщини міста та обласTi;

- корінна модернізація транспортно-дорожньої інфраструктури міста та області: дороги, розв'язки, стоянки;

- впровадження міжнародних стандартів берегового обслуговування туристів;

- створення сучасної портової інфраструктури;

- розробка гнучкої системи портових зборів для круїзних суден (знижки в залежності від числа суднозаходів на рік).

- завершення оновлення аеропорту. 
Безумовно, що залучення міжнародних круїзних ліній на Чорне море i, зокрема, збільшення кількості суднозаходів іноземних круїзних лайнерів у порт Одеса $\epsilon$ важливим завданням. Однак, потрібно розуміти, що круїзний ринок Чорного моря є периферією для великих світових компаній. Для них існує багато інших альтернатив, зокрема стрімко розвиваються ринки Китаю, Індії, країн Південно-Східної Азії.

Висновки. Таким чином, за результатами аналізу галузі і перспек- тив іiі розвитку, можна зробити висновок, що, хоча за результатами соціально-економічного аналізу транспорт та туризм не увійшли до переліку пріоритетних галузей виробництва в Одеській області, іiі регіональна стратегія повинна включати інноваційні заходи щодо відродження i зміцнення позицій міжнародного круїзного туризму в Одеській області, що в свою чергу позитивно позначиться на бюджеті всіх рівнів.

\section{СПИСОК ЛІТЕРАТУРИ}

1. Foray D., Van Ark B. Smart specialization in a truly integrated research area is the key to attracting more R\&D to Europe / Knowledge Economists Policy Brief No. 1. 2007. October. URL: http:/lec.europa.eu/invest_in_research/ monitoring/ knowledge en.htm.

2. David P., Foray D., Hall B. Smart Specialization. The concept. Knowledge Economists Policy Bries 9, October 2007. P. 20-24.

3. Бжуска Я., Пика Я. Розумна спеціалізаиія регіону // Вісник Національного університету Львівська політехніка. 2012. о 749: Логістика. С. 362-366.

4. Дубинський Г.П. Стратегія розумної спеціалізації для України // Соџіальна економіка. 2017. Вип. 53 (1). С. 59-68.

5. Нова регіональна політика для нової України: Аналітична доповідь (Скорочена версія) / [Жаліло Я.А., Жук В.І., Снігова О.Ю. та ін.]; під заг. ред. Я.А. Жаліла. К.: Інститут суспільно-економічних досліджень, 2017. 36 c.

6. Снеговая Е.Ю. Раскрытие потенциала смарт-спеииализации для преодоления региональной структурной инертности в Украине // Экономика Украины, 2018, № 8 (673). C.75-87.

7. Українські регіони залучатимуть фінансування з Свросоюзу // Укрінформ. URL: https://www.ukrinform.ua/rubric-economy/2536282-ukrainski-regioni-zalucatimutfinansuvanna-z-evrosouzu-mert.html

8. Методологія планування регіонального розвитку в Україні. Інструмент для розробки стратегій регіонального розвитку і планів їх реалізації Проект Європейського Союзу «Підтримка політики регіонального розвитку Украйни». URL: https://www.google.com/url? sa $=t \& r c t=j \& q=$ \&esrc $=s \& s o u r c e=w e b \& c d=$ $1 \& v e d=2 a h U K E w i 3 h 7$ DxZnmAhXopIsKHcczBvUQFjAAegQIAhAC\&url=https\%3A $\% 2 F \% 2 F$ surdp.eu\%2Fuploads\%2Ffiles\%2FMethodology_of_RD_planning.pdf\&usg $=A O v \operatorname{Vaw1}$ EBvxNphNkZOUfqh3ZTIRd. 
9. Gedminaitè-Raudonè Z, Vidickiené D., Vilké R. Unused potential for Smart Specialization development through collaboration: Lithuanian case // Agricultural Economics - Czech, 65, 2019 (10): 463-469.

10. В Одеській області розпочато реалізачію проекту $С С$ «Смарт-спеціалізачія» // Oфіційний сайт Одеської обласної державної адміністрації. URL: https://da.odessa.gov.ua/news/v-odeskij-oblasti-rozpocato-realizaciu-proektu-essmart-specializacia

11. Полякова Ю.В. Інноваційний потенціал регіонів України // Науковий вісник Ужгородського національного університету. 2016. Випуск 6, частина 2. C. 168-171.

12. Cruise Industry News Annual Report and Industry Growth Forecast. Official website. URL: https://www.cruiseindustrynews.com/annual-cruise-industry-report.html

13. Туристичні оператори «Фенікс Райзен», «Азамара», «Крістал Крузес» знову включають Одесу у маршрути круїзів // Морські бізнес-новини Украӥни. URL: https://maritimebusinessnews.com.ua

\section{REFERENCES}

1. Foray, D. \& Van Ark, B. (2007). Smart specialization in a truly integrated research area is the key to attracting more $R \& D$ to Europe. Knowledge Economists Policy Brief No. 1, October. Retrieved from http:/lec.europa.eu/ invest_in_research/pdf/ download_en/policy_brief1.pdf.

2. David, P., Foray, D. \& Hall, B. (2007). Smart Specialization. The concept. Knowledge Economists Policy Bries 9, P. 20-24

3. Bzhuska, Ya. \& Pyka, Ya. (2012). Rozumna spetsializatsiia rehionu [Reaso-nable specialization of the region]. Visnyk Natsionalnoho universytetu «Lvivska politekhnika» - Bulletin of the National University of Lviv Polytechnic. No 749: Lohistyka, 362-366 [in Ukrainian].

4. Dubyns 'kyi, G.P. (2017). Stratehiya rozumnoi spetsializatsii dlya Ukrainy [Intelligent specialization strategy for Ukraine]. Sotsial'na ekonomika - Social Economy. Iss. 53 (1), pp. 59-68 [in Ukrainian].

5. Zhalilo Ya. A., Zhuk V. I. \& Snihova O. Yu. etc (2017). Nova rehionalna polityka dlia novoi Ukrainy: Analitychna dopovid (Skorochena versiia) [New Regional Policy for a New Ukraine: An Analytical Report (Abridged Version)]. K.: Instytut suspilnoekonomichnykh doslidzhen - Institute of Social and Economic Research, 36 p. [in Ukrainian].

6. Snegovaya, E.U. (2018). Raskrytie potenciala smart-specializacii dlya preodoleniya regionalnoy strukturnoy inertnosti $v$ Ukraine [Unleashing the potential of smart specialization to overcome regional structural inertia in Ukraine]. Ekonomika Ukrainy-Ukrainian economy, \#8 (673). P. 75-87 [in Russian].

7. Ukraynski regiony zaluchatymut' finansuvannya z Eurosouzu [Ukrainian regions will attract funding from the European Union]. Ukrinform. Retrieved from https://www. ukrinform.ua/rubric-economy/2536282-ukrainski-regioni-zalucatimut-finansuvannaz-evrosouzu-mert.html [in Ukraine]. 
8. Metodologiya planuvannya regionalnogo rozvytku $v$ Ukraine. Instrument dlya rozrobky strategiy regionalnogo rozvytku i planiv ih realizaciyi. Proekt Evropeyskogo Souzu «Pidtrymka polityky regionalnogo rozvytku Ukrainy» [Methodology for regional development planning in Ukraine. A tool for developing regional development strategies and plans for their implemen-tation The European Union project «Supporting Ukraine's Regional Deve-lopment Policy». Retrieved from https://www.google.com/url? sa $=t \& r c t=j \& q=\&$ esrc $=s \&$ source $=$ web\&cd $=1 \& v e d=$ 2ahUKEwi3h7 DxZnmAhXopIsKHcczBvUQFjAAegQIAhAC\&url=https\%3A\%2F\%2 Fsurdp.eu\%2Fuploads\%2Ffiles\%2FMethodology_of_RD_planning.pdf\&usg $=A O v V a$ wlEBvxNphNkZ0Ufqh3ZTlRd [in Ukrainian]

9. Gedminaite-Raudonè Z, Vidickiene D. \& Vilkè R. (2019). Unused potential for Smart Specialization development through collaboration: Lithuanian case. Agricultural Economics - Czech, 65, (10), 463-469.

10. V Odeskiy oblasti rozpochato realizaciu proektu EU «Smart-specializaciya» [Implementation of EU Smart Specialization project started in Odessa region]. Official website Odeskoy oblastnoy derzhavnoy administracii - Official site of Odessa Regional State Administration. Retrieved from https://oda.odessa.gov.ua/news $/ v$ odeskij-oblasti-rozpocato-realizaciu-proektu-es-smart-specializacia [in Ukraine].

11. Polyakova, U.V. (2016). Innovaciyniy potencial regioniv Ukrainy [Innovative potential of Ukrainian regions]. Naukoviy visnyk Uzhgorodskogo nacionalnogo universitetu - Scientific Bulletin of Uzhgorod National University, vypusk 6, chast 2, P.168-171 [in Ukrainian].

12. Cruise Industry News Annual Report and Industry Growth Forecast. Official website. URL: https://www.cruiseindustrynews.com/annual-cruise-industry-report. html

13. Turystychni operatory "Fenix Risen», «Azamara», "Cristal cruises» znovu vkluchaut Odesu v marshruty kruiziv [Travel operators «Phoenix Reisen», «Azamara», "Crystal Cruises» again include Odessa in cruise routes]. Maritime business news of Ukraine. Retrieved from https://maritimebusiness-news.com.ua [in Ukraine].

Стаття надійшла до редакції 06.11.2019

Посилання на статтю: Савельєва I. В. Розвиток круїзного туризму в умовах використання методики смарт-спеціалізації одеської області // Розвиток методів управління та господарювання на транспорті: Зб. наук. праць, 2019. № 4 (69). C. 5-14. DOI 10.31375/2226-1915-2019-4-5-14.

Article received 06.11.2019

Reference a JournalArtic: Savelieva I.V. (2019). Cruise tourism development under the conditions of smart specialization techniques. Development of management and entrepreneurship methods on transport, 4, 5-17. DOI 10.31375/2226-1915-2019-4-5-17. 